Bulletin d'études orientales

\title{
The Jurisdictional Limits of Qâdị Courts during the Umayyad Period
}

\section{Steven Judd}

\section{(2) OpenEdition \\ Journals}

Electronic version

URL: http://journals.openedition.org/beo/3227

DOI: $10.4000 /$ beo.3227

ISSN: 2077-4079

\section{Publisher}

Presses de l'Institut français du Proche-Orient

\section{Printed version}

Date of publication: 1 April 2015

Number of pages: $43-56$

ISBN: 978-2-35159-707-1

ISSN: 0253-1623

\section{Electronic reference}

Steven Judd, "The Jurisdictional Limits of Qādī Courts during the Umayyad Period », Bulletin d'études orientales [Online], LXIII | 2015, Online since 01 April 2017, connection on 30 April 2019. URL : http:// journals.openedition.org/beo/3227 ; DOI : 10.4000/beo.3227 


\title{
The Jurisdictional Limits of $Q \bar{a} d \bar{l}$ Courts during the Umayyad Period
}

Steven JUDD

\begin{abstract}
This paper examines the function and jurisdiction of the qā di during the Umayyad period, focusing on the limits of the $q \bar{a} d \vec{\imath}$ s power and on his relationship to other power holders in Umayyad society. Based on an examination of biographies of more than seventy Umayyad $q \bar{a} d \bar{l}$-s, this paper demonstrates that qādì-s had unquestioned jurisdiction over marriage, divorce, inheritance, and other "family law". Neither local elites nor political leaders were above the $q \bar{a} d \bar{l}$ in such cases. However, the qādì had no jurisdiction over cases involving rebels and heretics. Nor did they determine the division of spoils. These examples suggest that the jurisdictional limits of qā $\bar{d} \bar{c}$ courts were well-established during the Umayyad period.
\end{abstract}

Keywords: Umayyads, Qadi, Courts, arbiter, Marriage and divorce, Inheritance, Heresy.

Résumé : Cet article examine les fonctions et les compétences du cadi à l'époque omeyyade, en s'interrogeant sur les limites de son pouvoir et sur sa relation à d'autres autorités de la société omeyyade. Fondé sur un examen des biographies de plus de soixante-dix cadis, l'article démontre que ceux-ci avaient une compétence incontestée sur les affaires de mariage, de divorce, d'héritage et relevant d'autres domaines du « droit de la famille ». Ni les élites locales, ni les dirigeants politiques n'étaient au-dessus du cadi dans de tels cas. Toutefois, le cadi n'avait pas juridiction sur les cas impliquant les rebelles et les hérétiques. Ils ne pouvaient pas non plus se prononcer sur la division du butin. Ces exemples suggèrent que les limites juridictionnelles des tribunaux de cadis étaient bien établies à l'époque omeyyade.

Mots-clés : Omeyyades, cadi, tribunaux, arbitre, mariage et divorce, successions, hérésie.

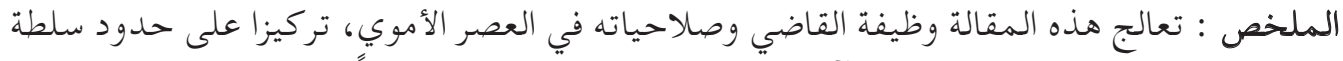

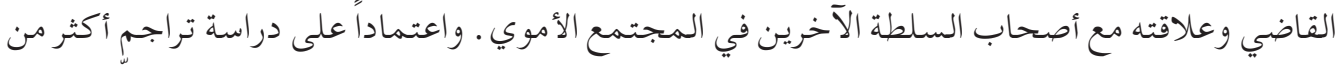

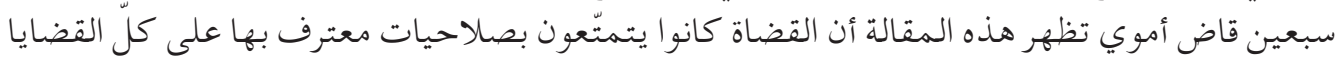

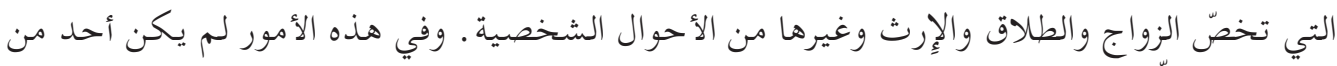

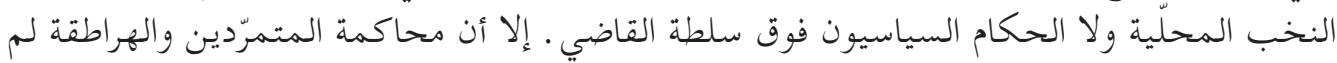


تدخل في صلاحيات القضاة، كما أنهم لم يقدروا على توزيع الغنائم. فتظهر هذه الأمثال أن حدود صلاحيات محكمة القاضي كانت ثابتة في العصر الأموي. الكلمات المحوريّة : دولة بني أمية، القضاة، مجلس القضاء، حَكَم، الزواج والطلاق، وراثة، هرطقة. 
The qā $\bar{d} \bar{\imath}$ is one of the few officials in early Islamic administration consistently mentioned in the sources. Medieval chroniclers, such as Haliffa b. Hayyāt (d. 240/854) and al-Ṭabarī (d. 310/923) typically list those who served as qā the Umayyad period, along with those who acted as governors and heads of the police

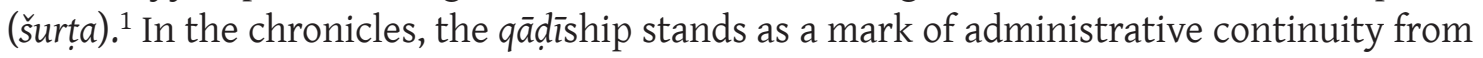
the time of the Rāšidūn forward. Despite the longevity of the qādiship and its obvious importance both for administrative order and for the articulation of Islamic legal doctrine, little is preserved about the actual functioning of the qā Archival records have not survived, assuming such records ever existed. Nor are other judicial documents or procedural manuals from the Umayyad period extant. Consequently, analyses of the Umayyad era qā the 'Abbāsid period. These sources bring with them a variety of assumptions about the nature of the qā $\bar{d} \bar{s}$ hip, derived from later authors' understandings of the origins of more formalized 'Abbāsid-era institutions. These assumptions have informed, and in some cases distorted, both medieval and modern discussions of the qădiship during the Umayyad period. Moreover, later 'Abbāsid-era discussions of the jurisdiction of the qā $\bar{l} \bar{l}$ courts occurred after the emergence of the mazälim courts, which could offer an alternative legal venue and whose functions could overlap with those of the qādi courts. As a result, these later treatments of the qādìship could project 'Abbāsid-era delineations of authority between the two court systems onto the Umayyad period, when only one of the two institutions existed, at least formally.

The discussion that follows will focus narrowly on jurisdictional boundaries, in an effort to delineate the extent of the qād $\vec{\imath}$ s legal jurisdiction during the Umayyad period. It begins with a summary of traditional views of the $q \bar{a} d \vec{\imath}$ s function and jurisdiction. Then it turns to a more focused examination of cases described in the sources, offering insights into the extent of the qā $\bar{d} \bar{i}-\mathrm{s}^{\prime}$ jurisdiction based on cases they purportedly heard. Finally, it will offer a more nuanced understanding of the jurisdictional limits of the qādi $\imath^{\prime}$ authority and demonstrate the real power $q \bar{a} d \bar{l}$-s could wield.

Modern scholarship has produced two divergent, though occasionally overlapping views of the nature and origin of the early Islamic qādiship. The first interpretation treats the qā $\bar{d} \bar{l}$ as essentially an Islamized version of the tribal hakam. In Arabian traditional society, hakam-s served as arbitrators to resolve disputes within their individual tribal communities. They were respected for their wisdom, fairness, and understanding of tribal customs. Perhaps their skills as negotiators were as important as their knowledge of customs, since their authority required the consent of those between whom they judged and they lacked any coercive capacity to impose their decisions. The consequences of defying the hakam's judgments are not specific. Presumably, those who reneged on promises to accept arbitration while simultaneously showing disrespect for a prestigious member of the community would suffer damage to their honor and, in extreme cases, might inspire

1. Halīfa b. Hayyāț, Ta'rīhn; al-Ṭabarī, Ta'rīh al-rusul wa-l-mulūk. 
retribution from the community at large. However, there was no formal mechanism for enforcement of the hakam's rulings or punishment of the recalcitrant.

According to this interpretation, the arrival of Islam meant that these traditional dispute adjudicators were still prestigious members of the community who were considered to be wise and fair, but that they were now appointed, or at least sanctioned, by the caliph or governor. Consequently, the qādi was ultimately a holdover from earlier Arabian tribal culture, now with an Islamic hue and the additional authority conveyed by caliphal endorsement. This view has been common in modern scholarship on early Islamic law. Joseph Schacht was explicit in asserting that the qādi "took over the seat and wand of the hakam". ${ }^{2}$

The second interpretive approach to the qādīship treats the qādi as an administrative extension of the governor and/or the caliph himself. This understanding of the office of $q \bar{a} d \bar{l}$ presumes a more centralized, autocratic approach to legal administration. According to this model, the qādi serves as an enforcer of caliphal rules and regulations, imposing caliphally-sanctioned uniformity on the community. It is through this enforcement function that the qā $\mathfrak{i}$ implements the so-called "Umayyad administrative practice" described by Joseph Schacht. ${ }^{3}$ The uniformity implied by this understanding of the qãdiship restricts the $q \bar{a} d \vec{\imath} \imath$ independence to a significant extent. No longer is he judging based on the nuances of individual cases and the best interests of the parties, as an arbitrator would. Instead, he is imposing rulings predetermined by the governor or the caliph. His function becomes more administrative under this model.

Another consequence of this interpretation is that the qād $\vec{\imath}$ s jurisdiction is constrained by the governor's oversight function. As an extension of the governor, the qā $\bar{l} \bar{c}$ cannot contradict the governor's will, since his superior can overturn his decisions. Moreover, the governor can choose not to delegate his judicial authority to anyone, retaining the $q \bar{a} d \vec{\imath}$ s powers for himself. This view has been presented most clearly by Emile Tyan, who envisioned a hierarchy of authority from the caliph to the governor to the qādi.$^{4}$ Schacht also expressed this view, asserting that, "[d]uring the Umaiyad period the administration of justice lay in the hands of the provincial governors and, in so far as special judges were appointed, they were agents of the governors to whom these last delegated part of their functions". ${ }^{5}$ More recently, similar views have been adopted by Mathieu Tillier. ${ }^{6}$ To some extent, Schacht tries to have it both ways, asserting that the qā governor somehow retains "full authority". ${ }^{7}$ More recently, Wael Hallaq has espoused a similar, apparently contradictory view. He asserts on the one hand that the early qāạ $\bar{\imath}$

\footnotetext{
2. SCHACHT 1964, p. 24.

3. SCHACHT 1950, p. 190 ff.

4. TYAN 1960, p. 132 ff.

5. SCHACHT 1950, p. 191.

6. TILLIER 2009, p. 496-504.

7. SCHACHT 1964, p. 25.
} 
was essentially a hakam, but also describes him as the "commander's assistant" who was "usually subservient" to the amir. ${ }^{8}$

These divergent views of the origin and function of the qāaiship derive from two central themes in scholarship on Umayyad-era institutions. On the one hand, modern scholars have tried to find evidence of continuity with the pre-Islamic past by focusing upon similarities between Umayyad-era institutions and earlier Arabian, Byzantine or Sasanian precursors. Hence, the qā functionary who now cloaks his rulings in Islamic rather than customary garb. On the other hand, modern scholars have tried to fill the documentary void of the Umayyad period by relying on 'Abbāsid-era sources and assuming that bureaucratic structures described therein have earlier precedents in the Umayyad era. This approach accepts that the hierarchical structures created by the reforms of several 'Abbāsid caliphs, described in detail by Mathieu Tillier, had earlier roots. ${ }^{9}$ This image of Umayyad judicial order also reflects to some extent the idealized vision of the judiciary presented in the various adab al-qā $\bar{d} \bar{\imath}$ sources, which were written long after the Umayyad period.

An examination of other, less idealized sources, especially the biographical literature, offers a different vision of the qādiship and its jurisdiction during the Umayyad period. As the discussion below will demonstrate, the qā obedient arm of the governor. Instead, the extent of the qāa $\vec{\imath} s$ authority and the boundaries of his jurisdiction were more complicated and, perhaps surprisingly, more clearly defined.

To come to this conclusion, it is necessary to examine the kinds of cases qādi $\bar{i}-\mathrm{s}$ purportedly heard and to note as well the kinds of cases that they were not allowed to adjudicate. Analysis of actual cases allows us to understand both the legal limits of the $q \bar{a} d \hat{\imath} \vec{s}$ jurisdiction and the extent of his authority over various classes of people, elite and otherwise. Fortunately, accounts of some, though by no means many, of the cases heard by Umayyad qā

While the qādi courts of the Umayyad era had nothing resembling archives, reports of a fair number of cases survive in other sources. In particular, the Ahbār al-qudāt of Wakĩ (d. 306/918) and the Ahbār qudāt Mișr of al-Kindī (d. 350/961) include numerous anecdotes describing qādī-s' activities. ${ }^{10}$ In addition, entries on individual $q \bar{a} d \bar{l}$-s found in the biographical sources provide important data. Accounts of cases included in these sources do provide useful insights into the extent of the qādì's jurisdiction, but their limitations must not be ignored. These are not complete archives, and their compilers did not intend for them to serve such an administrative function. Instead, these sources include only those cases that later compilers found to be important or interesting for a variety of reasons. The bases for their decisions about what to record and what to discard are not explicit. Nor is there any clear indication about the degree of comprehensiveness of the sources

\footnotetext{
8. HALlaQ 2005, p. 35-37.

9. TILLIER 2009, p. 101-135.

10. Wakī, Ahbār al-quḍāt; al-Kindī, Ahbār quḍāt Miṣr.
} 
from which they drew their materials. Accounts of many of the Umayyad qā no references to specific cases, while others include numerous anecdotes about individual cases. The cases discussed below were culled from an examination of biographical and other accounts of some 75 Umayyad-era $q \bar{a} d \bar{l}$-s. The data represents neither a comprehensive nor a random sampling of these cases. Instead, these examples are included because they offer insights into the structure and functioning of the Umayyad-era qā institution's Umayyad roots were perceived in later times.

\section{The $q \bar{a} d \bar{l}^{\prime}$ 's areas of jurisdiction}

The majority of cases described in these sources involve what modern scholars would call "family law", disputes about marriage, divorce and inheritance. Cases involving marriage and divorce are particularly common. Some of these cases are mundane. For instance, Wakî̀ reports that Sa īd b. Ušū'a, the Umayyad qā dī in Kufa from 105-113/724-731, dissolved an improper marriage. Wakî does not name the litigants nor does he offer details about the nature of the impropriety. It is clear, however, that there was no conflict about the $q \bar{a} d \hat{\imath}$ 's authority to judge whether the marriage was valid. ${ }^{11}$ In Egypt, Yūnus b. 'Atiyya, who served as qā about maintenance payments for a divorced wife. Again, details of the case (and even his opinion) are not included. ${ }^{12}$ Tawba b. Namir, the Egyptian qā $\bar{\imath} \bar{\imath}$ from 115-120/733-738, ordered a divorced man to pay compensation to his ex-wife and then refused to accept the man's future testimony after he defied the qā $\bar{d}_{i}{ }^{13}$

Other marriage and divorce cases were more complicated and more interesting. For instance, the Bașran qā dị Iyās b. Mu'āwiya (served 99-101/717-719) adjudicated a confusing divorce case in which the husband claimed that the divorce was invalid because he was drunk at the time. ${ }^{14}$ The two accounts Wakî includes differ over important details, even regarding the identity of the parties. In the first version, both spouses were members of the powerful Muhallabī family. When the wife refused a cup of wine offered by her husband, he proclaimed that he would divorce her if she did not drink (anti țāliq țalātan in lam tašrabī-hi). After her continued refusal (and a smashed wine cup) she claimed that he had divorced her, but he denied that he had actually pronounced the triple repudiation. In this version, Iyās affirmed the divorce based on testimony from unnamed women who were present. In Wakî's second account, the parties are not named. The husband is identified as a member of the Bānū Kirām who was a brother-in-law to the governor, and the wife is simply from al-Huddān. In this version, the ex-wife rebutted his claim of drunkenness through the

\footnotetext{
11. Wakī , Ahbār al-quḍāt, III, p. 19-20.

12. Al-Kindī, Ahbār qud̄āt Mișr, p. 322-323.

13. Al-Kindī, Ahbār quḍāt Mișr, p. 344.

14. Wak̄̄̄, Ahbār al-qud̄āt, I, p. 313-316.
} 
testimony of her recently-freed slave, who asserted that the husband was sober. The qādi $\vec{\imath} s$ affirmation of the divorce sparked the ire of the governor, 'Adī b. Arțāt, and forced Iyās to flee. These anecdotes obviously touch upon a variety of complicated legal questions, including the application of the triple repudiation in a single incident, the effect of drunkenness on one's competence to divorce, and the admissibility of testimony from female witnesses and freed slaves (whose manumission may have been a quid pro quo). The demonstration of the power dynamics between influential families, governors and $q \bar{a} d \bar{l}$-s is also important. It is possible to draw a broad range of conclusions about Umayyad jurisprudence from this case alone, assuming that it represents normative practice and is not merely an entertaining story.

In another example, the Medinan qāọ̄ Abū Bakr b. 'Abd al-Raḥmān (c. 114/732) rejected the legitimacy of a marriage that occurred without the consent of the bride's family. Elopements and consequent unhappy families were likely as common in early Islamic times as they are today. What was unusual about this case, however, was that the groom was Ayyūb b. Salama, the caliph Hišām's uncle and the eloping bride was Fâtima, the granddaughter of al-Hasan b. 'Alī b. Abī Țālib. Her four brothers objected to the union and brought the matter before the governor who referred the case to the qāa $\bar{\imath} .{ }^{15}$ The qā $d \bar{\imath}$ rejected the marriage, sparking the ire of Ayyūb, who refused to accept the $q \bar{a} d \vec{\imath}$ s decision and subsequently received a beating for his recalcitrance. Ayyūb then turned to his nephew the caliph, seeking his intervention. Hišām's response was somewhat confusing. He scolded his uncle and threatened to subject him to a worse beating, but then ultimately assisted him. He scolded the governor and ordered him to be beaten as well. However, the caliph also ordered all parties to accept the bride's decision in the matter. Like the previous case, this was no typical marriage case and had significant social and legal implications. The caliph's uncle was condemned for trying to circumvent the qā $\bar{d} \bar{l}$, but the compromise allowed a prestigious woman to marry despite the objections of her family. The caliph also insulated the qā $\mathfrak{d} \bar{\imath}$ from any retaliation for ruling against his kinsman, focusing his ire on the governor instead. This story also has obvious 'Alid-Umayyad undertones, ultimately disempowering the 'Alid men in the story by undermining their control over Fâtima's marriage. Significantly, the story ends with the simple statement that the two did not produce offspring. Here again, powerful figures in society clashed in a case in which basic legal principles were at stake. In each of these cases, the qādī survived relatively unscathed, despite passing judgments against the interests of the powerful.

$Q \bar{a} d \bar{l}$-s also heard a variety of inheritance cases. Many of those reported deal with the mathematical intricacies of the proper division of an estate among different combinations of survivors. Some cases offer more specific legal and societal commentary. For instance, the Egyptian qā

15. Wakî̀, Ahbār al-qudāt, I, p. 172-174. There is some confusion in the report about whether Abū Bakr or 'Ubayd Allāh b. Șafwān was the qā ḍi who heard the case. 
slave given a contract of emancipation) could not inherit. ${ }^{16}$ In a related area, al-Kindī also reports examples wherein the qād $\bar{\imath}$ was responsible for arranging the administration of the inheritance of minor orphans. ${ }^{17}$ In a more politically charged case, the Medinan qā $\bar{\imath} \bar{\imath}$ Sa $d$ b. Ibrahīm (c. 104/722) ruled that Ismāīl b. 'Abd Allāh, the head of Qurayš in Medina, was required to provide funds to a needy kinsman. ${ }^{18}$ These examples involving "family law" illustrate the solutions the $q \bar{a} \bar{d} \bar{l}-s$ found to sometimes confusing legal problems, but they also offer insights into the social and political power structure of the community.

Cases involving the $q \bar{a} d \vec{\imath}$ s evaluation of the admissibility of certain types of witnesses also served multiple functions. While these cases are not numerous in the sources, they are instructive. For instance, the divorce case discussed above illustrates the consequences of a $q \bar{a} d \vec{\imath} \vec{s}$ determination of whether women or freed slaves could testify in such cases, offering hints about their social and legal status. In another example, the legendary Kūfan qā dī Šurayḥ b. al-Hāarit (c. 22-79/643-698?) refused to hear the testimony of a son to confirm his father's accusations, due to his inherent conflict of interest. Šurayh applied this standard even in a case in which the son in question was al-Hasan b. 'Alì, the heir to the reigning caliph. ${ }^{19}$ In this example, the rules of evidence were applied uniformly, despite the prestige of the litigant and witness, neither of whom objected to Surayh's ruling. The sources record other examples of $q \bar{a} d \bar{l}-s$ rejecting testimony for a variety of reasons. For instance, the Egyptian qā testimony from a man who had defied him in a previous case. ${ }^{20}$ The Damascene $q \bar{a} d \bar{l}$, Bilāl b. Abī al-Dardā' (60-65/678-684) not only refused testimony from dishonest witnesses, but reportedly beat them and, in some cases, tied them to the columns of the mosque to humiliate them publicly. ${ }^{21}$ These reports do not name the alleged liars, but suggest that the qā $\bar{\imath} \bar{\imath}$ had broad latitude to determine who would be heard in his court and to impose consequences for perjury or defiance. Other reports are less specific, simply noting kinds of testimony particular $q \bar{a} d \bar{\imath}-s$ would admit. For example, the Egyptian qā $\bar{d} \bar{\imath}$ Hayr b. Nu'aym (120-127/738-745) would allow testimony from Christians, Jews and youths in some cases. ${ }^{22}$ The Medinan qā dì Salama b. 'Abd Allāh (101-104/719-722) permitted testimony from youths as well. ${ }^{23}$ The earlier Medinan qā $\bar{d} \bar{\imath}$ Abū Bakr b. Muhammad al-Anșārī (93-96/711-714) accepted the testimony of a son on behalf of his mother, in contrast to Šurayh's rejection of testimony on behalf of one's parents. Abū Bakr also accepted the testimony of someone

\footnotetext{
16. Al-Kindī, Ahbō̄r quạāt Mișr, p. 350-351.

17. Al-Kindī, Ahbār quḍāt Mișr, p. 325, 341; al-Mizzī, Tahd̄īb al-kamāl, XVII, p. 412.

18. Wakī̄, Ahbār al-qud̄àt, I, p. 154-155.

19. Ibn 'Asākir, Ta'rīh madīnat Dimašq, XXIII, p. 26.

20. Al-Kindī, Ahbār qud̄āt Mișr, p. 344.

21. Ibn 'Asākir, Ta'rīh madīnat Dimašq, X, p. 526; al-Mizzī, Tahd̄īb al-kamāl, IV, p. 286.

22. Al-Kindī, Ahbār qud̄āt Mișr, p. 350-351.

23. Wakī', Ahbār al-qud̄āt, I, p. 148-150.
} 
who had previously made false accusations. ${ }^{24}$ While these Umayyad-era examples do not yet point to fixed rules about whose testimony is accepted under what circumstances, they do illustrate that the qā $\bar{d} \bar{\imath}$ had a degree of discretion in determining what evidence to accept and that the social status of the litigants was largely irrelevant to the determination of whether their testimony would be admitted.

In addition to these types of cases, the sources preserve a number of reports involving property disputes of various sorts. For example, Sa'd b. Ibrahim had to determine ownership of a wādì that was disputed between descendents of 'Alī and Mu'āwiyya. ${ }^{25}$ In another Medinan case, his successor, Sa īd b. Sulaymān (104-106/722-724) ruled against the governor, 'Abd al-Wāhid for extorting money from villagers outside Medina. ${ }^{26}$ In one of the only Umayyad-era cases recorded that involved a wrongful death, the Egyptian qādi 'Iyād b. 'Ubayd Allāh (93-100/711-718) determined that a mawla who was using a horse (rather than the horse's owner) was required to pay the blood price for a woman whom the horse ran over and killed. ${ }^{27}$ As in the "family law" examples, the cases that were preserved offered implicit commentary both on legal technicalities and society at large. They offer glimpses of interactions between elites and common people, including unnamed villagers

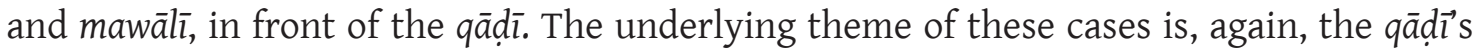
extensive authority over litigants from all elements of society.

The consistency of this theme suggests that one of the agendas Wakī al-Kindī and others pursued was to offer a commentary on the extent of the qā the Umayyad period. Clearly, these are not "normal" mundane cases that one would find in a true administrative archive, nor are they random collections of anecdotes. Instead, later compilers found these cases worthy of preservation for two apparent reasons.

First, a number of these and similar cases offer solutions to specific legal problems.

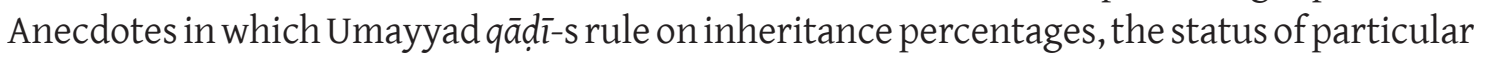
witnesses, the validity of marriages, and other questions have legal significance. They can provide precedents for later legal practice or, perhaps, criticism of later digressions from ideal practice. Whether these anecdotes are genuine representations of Umayyad judicial practice or apocryphal reports to justify later practice is, of course, still open to debate.

The second apparent purpose for these anecdotes is to offer insights into the nature and

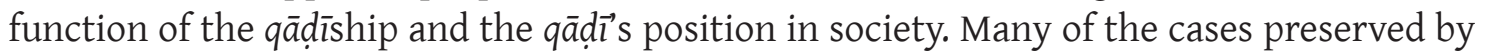
Wakī, al-Kindī and the biographical sources demonstrate the power dynamics in Umayyad society. Many of the cases mentioned above, and others like them, describe the qād $\bar{\imath}$ imposing his will on powerful members of society. For example, Sa'd b. Ibrāhīm resisted the defiant chief of Qurayš, Sa īd b. Sulaymān passed judgment against the governor who had

\footnotetext{
24. Wakī, Ahbār al-quḍāt, I, p. 144, 146.

25. Wakî̀, Ahbār al-qud̄āt, I, p. 153-154.

26. Wakī̄ Ahbār al-quḍāt, I, p. 167-168; al-Mizzī̄, Tahdī̄b al-kamāl, X, p. 483.

27. Al-Kindī, Ahbāar qudāàt Miṣr, p. 333-334.
} 
appointed him, and Abū Bakr b. 'Abd al-Rahmmān ruled against the caliph's own kinsman without suffering repercussions.

These cases may, in part, have served to glorify particular qā $\bar{d} \bar{l}-\mathrm{s}$ by showing their fearlessness in the face of power. Such demonstrations of independence were perhaps necessary for separating their legacies from their Umayyad masters. The scholars who served as $q \bar{a} d \bar{i}-s$ for the Umayyads were typically respected muhaddit-s, whose importance to the enterprise of hadit transmission outlived them. These scholars were necessary links between later traditionists and earlier generations. However, their service to the Umayyad dynasty, which later 'Abbāsid scholars denigrated for its immorality, could tarnish their legacies. Illustrations of their independence could blunt accusations of complicity with their Umayyad employers. Hence, one cannot entirely dismiss the potential polemical importance of these reports.

At the same time, however, these cases also demonstrate important assumptions about the extent of the qā $\bar{l}_{i}$ sjurisdiction, which do not appear to support a narrative of underlying resistance to the Umayyad authorities. The examples discussed above indicate that the political and social status of the litigants did not place them outside the qād $\vec{\imath}$ s jurisdiction or beyond his reach. In these cases, neither tribal connections nor political position tainted the qā $\mathfrak{i} \vec{\imath}$ s objectivity. In this regard, the case in which Sa îd b. Sulaymān ruled against the governor of Medina is particularly important. This case clearly demonstrates that the qādi was not merely the arm of the governor who appointed him, but that the governor himself

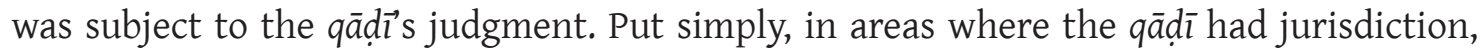
exceptions were not made for rank or office. While these cases are not numerous, they are consistent in emphasizing the $q \bar{a} d \vec{\imath} \mathbf{s}$ authority. Moreover, they are not told in a manner that appears to be intent on glorifying the anti-elite escapades of the qādi $\bar{i}$ but rather in a manner that underscores the futility of attempting to evade the authority inherent to the $q \bar{a} d \vec{\imath}$ s position.

\section{Areas outside the jurisdiction of the $q \bar{a} d \bar{l} \bar{l}$}

Before turning to areas where the qā important to pause to consider an important lacuna in the reports preserved in Wakî and other sources. In the reports associated with some 75 qādi $\overline{-}$-s examined in this study, there is a conspicuous absence of cases involving murder, or wrongful death of any sort. In fact, there are no examples of homicide cases heard by Umayyad qā $\bar{d} \bar{i}-\mathrm{s}$, or of disputes over the payment of blood prices (diya) or the proper amount of such payments. While it is possible that isolated cases may have been overlooked, it is surprising that murder cases do not appear to have attracted the attention of the sources. There are some references to qādi $\bar{l}-\mathrm{s}$ 
imposing hadd punishments, often at the mosque, but the context makes clear that these are beatings rather than amputations or executions. ${ }^{28}$

This silence about murder has several implications for our understanding of early Islamic society and jurisprudence. If, as suggested above, one of the purposes of the compilers of this material was to record power conflicts among the elites, why are there no murder cases? Surely families and clans of both victims and those accused would try to influence the proceedings in such cases. Powerful elites would be expected to attempt to bend the rules to their advantage in such critical circumstances. Such cases ought to have attracted a certain prurient interest from the public as well. Even in modern times, the drama of a murder trial outshines the most contentious celebrity divorce case or inheritance dispute. Yet, the Umayyad-era accounts are silent about such cases.

Are we to assume that murder cases were so universally mundane and legally insignificant that the sources did not bother to report them? Were there no questions about evidence or the admissibility of witnesses, issues that normally would have fallen to the qā $\bar{d}$ ? Are we to conclude that the rise of Islam produced such a harmonious society that homicides ceased? Or was there some other forum in which these cases were adjudicated? If so, it is not specifically mentioned in sources for the Umayyad period. These remain open questions for further investigation.

The lack of murder cases in accounts of the qādì-s has a broader implication for understanding early Islamic society. Traditional narratives, both Islamic and Orientalist, have treated the pre-Islamic period as one of lawlessness, dominated by incessant blood feuds. According to this narrative, Islam contained the blood feud and imposed legal dispute resolution processes instead. One would expect the adjudication of these disputes to be memorialized in accounts of the courts where these disputes ought to have been heard. If they were not heard by the qādi $\bar{i}$-s, then who adjudicated such cases and in what forum? The lack of such reports is puzzling and merits more inquiry.

We do find significant examples of other types of cases that were outside the qādi $\vec{\imath}$ jurisdiction, though this distinction is not described explicitly. Qādì-s did not adjudicate cases involving the trial and punishment of heretics and rebels, nor did they decide questions regarding the distribution of spoils during conquest. These cases fell under the direct jurisdiction of the caliph or the governor. In the case of spoils division, some authority was delegated to the amir in the field.

Wakî and al-Kindī do not describe Umayyad-era cases involving heretics and rebels. Such cases do, however, appear in the historical sources and in biographical reports of the participants. I have discussed these heresy trials extensively in other contexts and will not revisit these cases individually here. Instead, for the purpose of understanding the limits of the qā $\bar{\imath} \imath$ s jurisdiction, it is important simply to note that these cases were heard

28. For examples of beatings, see Ibn 'Asākir, Ta'rīh madīnat Dimašs, X, p. 256; XXIX, p. 281; Wakī', Ahbār al-quḍāt, I, p. 157, 173; II, p. 41; III, p. 8. I have found no descriptions of Umayyad qādì-s imposing amputations or executions. 
not by the $q \bar{a} d \bar{l}$, but by the governor or the caliph himself. It is clear that some sort of trial occurred in these instances, but it was not a trial before a qā $\bar{d} \bar{i}$.

For example, most reports indicate that the heretic Ma'bad al-Ğuhanī (d.c. 80/699) was tried and executed by the Iraqi governor al-Hağğăğ b. Yūsuf, or perhaps by the caliph 'Abd al-Malik himself. ${ }^{29} \mathrm{~A}$ few decades later, another celebrated heretic, al-Ǧa'd b. Dirham (d.c. 124/742) was tried and put to death by al-Hağğāğ's successor Hāalid al-Qasrī, who served as prosecutor, judge and executioner. ${ }^{30}$ None of the extant reports of these heresy trials mentions any role whatsoever for the qā $\bar{d}_{\bar{l}}$.

Reports on two other heresy cases do mention the participation of scholars who served as $q \bar{a} d \bar{l}$-s. These cases illustrate clearly that judging heretics was outside the parameters of the qā $\bar{d} \vec{\imath}$ s jurisdiction. Some accounts of the trial and execution of al-Hārit b. Sa īd al-Kad̄dāb (d. 80/699) indicate that a prominent muhaddit heard al-Hāarit proclaim his outrageous views and promptly reported al-Hārit to Abū Idrīs al-Hुawlānī, the qā dị in Damascus. The $q \bar{a} d \vec{\imath}$ s response is instructive. Rather than calling the alleged heretic before his court for questioning, Abū Idrīs informed the caliph of al-Hāriț's statements. 'Abd al-Malik himself then took action against al-Hārit. ${ }^{31}$ The qāḍ̄ clearly recognized that al-Hāriț's case was beyond his jurisdiction and referred the matter to the caliph. The only other heresy trial in which the qādī played a role was that of Ġaylān al-Dimašqī, in which al-Awzāì (d. 157/774) served as prosecutor rather than as qā dī. The caliph Hišām (r. 105-125/724-743) passed judgment on Ġaylān and sentenced him after hearing al-Awzāî̀'s interrogation of the suspected heretic. ${ }^{32}$ It is essential, however, to note that, while al-Awzāi may have served briefly as a qā reign. These two cases illustrate clearly that adjudicating heresy cases was beyond the

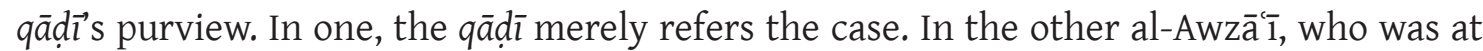
this time an advisor and possible future $q \bar{a} d \bar{l}$, served as prosecutor rather than judge.

Judging rebels was also beyond the boundaries of the qādi $\vec{\imath}$ jurisdiction. There are numerous examples of rebels being tried and put to death, but it is always the governor or the caliph who presides over these events. There are no Umayyad-era examples in which the $q \bar{a} d \bar{\imath}$ played any role at all in the adjudication of cases involving open rebellion. It appears that both doctrinal offenses and insurrections were outside the parameters of the qãd $\vec{\imath} s$ authority.

The distribution of spoils was also outside the $q \bar{a} d \vec{\imath}$ s jurisdiction. There is an extensive literature on the minutia of dividing the spoils of conquest in various siyar works. ${ }^{33}$ These works discuss in detail what constitutes legitimate spoils and how and when such riches could be divided among the troops. Nowhere in the literature on the Umayyad period is there any mention of a role for the qā ${ }^{\bar{l}} \bar{i}$ in the division of spoils. Religious scholars were

\footnotetext{
29. JUDD 2011, p. 4-6

30. JUDD 2011, p. 8-9

31. Ibn Ḥağar, Lisān al-mizān, II, p. 151-152; Wak̄̄ , Ahbār al-quḍāt, III, p. 202; al-Mizzī, Tahd̄īb al-kamāl, XXIII, p. $443-447$.

32. JUDD 1999 , p. 170-172

33. For the most extensive collection of Umayyad-era reports, see al-Fazārī, Kitāb al-siyar.
} 
certainly present at the frontier and offered expert opinions on a variety of issues, including a number of truly peculiar but plausible cases. However, they only offered advice and did not adjudicate. The office of qādìl-'askar, whose function is well-known in later periods, did not yet exist in the Umayyad period. ${ }^{34}$ Instead, authority over military encounters and their aftermaths rested solidly with the amir.

\section{Conclusion}

This examination of actual cases, or the absence of actual cases, can lead us to several conclusions about the extent of the Umayyad qā $d \vec{\imath} s$ jurisdiction. First, it is clear that the $q \bar{q} d \bar{\imath}$ was not merely an extension of the governor. In some areas of jurisdiction, such as rebellion, the governor did not rely on the qādi at all. In other areas, as several examples demonstrate, the qā

In general, the qā $\bar{l} \bar{l}$ appears to have had exclusive authority over disputes between litigants, in essence tort cases broadly defined to include criminal matters in which a victim suffered damages of some sort. These cases included property disputes, family law and crimes against individual victims (though perhaps not homicides). In these realms, the qā $\bar{\imath}_{\vec{\imath}} \mathrm{s}$ authority was absolute. Neither social status nor government position could undermine the qā $\bar{\imath}$ 's power. Several of the anecdotes described above illustrate the futility of efforts by elites to evade the qād $\vec{\imath}$ s judgment. The qādi did not, however, enjoy absolute autonomy. There are several examples in which the qād $\vec{\imath}$ s abuse of his office led to dismissal and punishment from the governor. At the same time, within his jurisdictional boundaries, the $q \bar{a} d \bar{l}$ generally could not be defied, even by the governor who appointed him.

The qā $\hat{l}_{i}$ s jurisdiction did not extend to what we would now describe as crimes against the state. Instances of rebellion, whether military or doctrinal, were outside the realm of the qādì s authority. These were not tort cases, or crimes against individuals, but political crimes that were adjudicated by the political leaders of the community. The distribution of spoils was also outside the qādi $\vec{\imath}$ s realm. Here, wealth acquired by the state through its military function was distributed to individual subjects. The military amir held authority over this process. Again, there was no tort-like dispute involved in questions of distribution of spoils. Questions centered instead on how the state should distribute its largesse.

The cases examined here suggest that the qād $\vec{\imath}$ s authority was more clearly defined than has been assumed. He was not merely an extension of the governor, whom he could defy and even punish in some circumstances. Instead, the qā $\bar{d} \bar{i}$ was perhaps closer to the pre-Islamic hakam, whose principal function was to resolve disputes between individual litigants. However, unlike the hakam, the qādì enjoyed a surprising degree of independence within the circumscribed sphere of his authority. He could defy those who appointed him, but only within the established, albeit unspoken, boundaries of his jurisdiction.

34. Regarding the qādì l-'askar during the early 'Abbāsid period, see TILLIER 2009, esp. p. 334 ff. 


\section{Bibliography}

\section{Sources}

Al-Fazārī, Kitāb al-siyar, Beirut, Mu'assasat al-Risāla, 1987.

Ibn 'Asākir, Ta'rīh madīnat Dimašq, ed. 'Umar al-'Umrawī, Beirut, Dār al-fikr, 1995, 80 vol.

Ibn Ḥağar al-'Asqalānī, Lisān al-mizān, Hyderabad, 1911-1913, 6 vol.

Halīfa b. Huyyāt, Ta’rīkh Halīfa b. Hayyāt, Najaf, Mațba'at al-adab, 1967.

Al-Kindī, Ahbār qudāt Miṣr in The Governors and Judges of Egypt, or Kitâb el 'umarâa (el wulâh) wa Kitâb el qudâh of el Kindî, ed. R. Guest, Leiden, Brill, 1912.

Al-Mizzī, Tahd̄īb al-kamāl fí asmä’ al-rijāl, Beirut, Mu'assasat al-Risāla, 1980-1992, 35 vol.

Al-Ṭabarī, Ta'rīh al-rusul wa-l-mulūk, ed. M.J. de Goeje, Leiden, Brill, 1879-1901, 15 vol.

Wak̂̄, Ahbār al-quḍāt, Cairo, Mațba at al-istiqāma, 1947-1950, 3 vol.

\section{Modern references}

HALLAQ, Wael B., 2005, The Origins and Evolution of Islamic Law, Cambridge, Cambridge University Press.

JUDD, Steven, 1999, "Ghaylān al-Dimashqī: The Isolation of a Heretic in Islamic Historiography", International Journal of Middle East Studies 31/2, p. 161-184.

DOI: http://dx.doi.org/10.1017/S0020743800054003

JuDD, Steven, 2011, "Muslim Persecution of Heretics during the Marwānid Period (64-132/684-750)", Al-Masāq 23/1, p. 1-14. DOI: http://dx.doi.org/10.1080/09503110.2011.552943

SCHACHT, Joseph, 1950, Origins of Muhammadan Jurisprudence, Oxford, Oxford University Press.

SCHACHT, Joseph, 1964, An Introduction to Islamic Law, Oxford, Clarendon Press.

TILLIER, Mathieu, 2009, Les cadis d'Iraq et l'État abbasside (132/750-334/945), Damascus, Presses de l'Ifpo (PIFD 235). [En ligne] http://books.openedition.org/ifpo/673 